Journal of Teaching English

Volume 4 No. 4, 2019

e-ISSN: 2548-6810

\title{
THE EFFECT OF KEEPING VOCABULARY NOTEBOOK ON STUDENTS' VOCABULARY ACHIEVEMENT AT THE SECOND GRADES IN SMP N 2 RAHA
}

\author{
Mauliddin Nuur ${ }^{1}$, Tambunan $^{2}$, Nurnia $^{3}$ \\ mauliddinnurmarifatullah@gmail.com \\ ${ }^{1}$ Halu Oleo University, Indonesia.
}

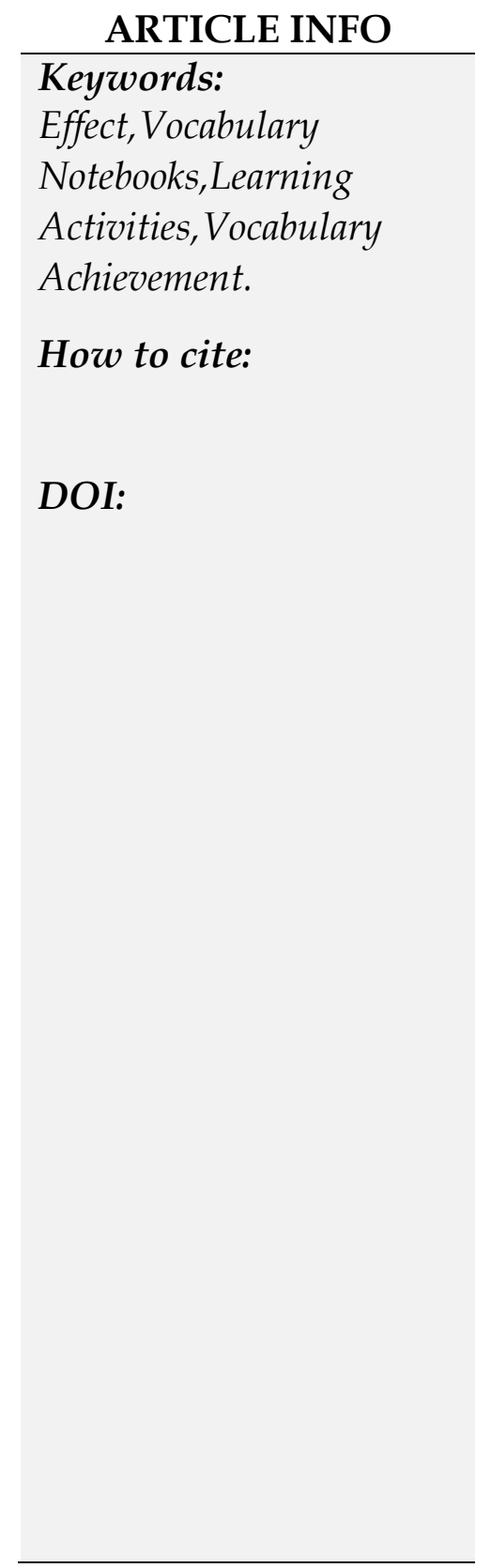

\begin{abstract}
This study investigated the effect of keeping vocabulary notebooks on students' vocabulary achievement at the second grade in SMPN 2 Raha. The purpose of this study is to find out a significant effect after keeping vocabulary notebook on students' vocabulary achievement. This study applied quantitative research design. This study used vocabulary notebook as a treatment in learning process for the students. The subject of this study was second grades students of SMPN 2 Raha who were registered in academy year 2017-2018. The technique of taking sample of study was purposive sampling. The sample of this study was class $\mathrm{VIII}^{2}$ as an experimental class and class VIII ${ }^{1}$ as a control class. The instrument of this study was vocabulary test consist of 30 numbers, the result showed that there was not a significant effect of keeping vocabulary notebooks on students' vocabulary . It was not proved with the improvement of students were the students more active in the classroom rather than the teacher. Students can discover the new words by themselves on the learning activities. the result of students' vocabulary test was supported with the mean score in post-test of experimental class is higher than the mean score in the post-test of control class. The mean score for the post-test in experimental class was 82.15 and the mean score for post-test in control class was 79.36. but the data was not distributed normally, the analysis of the data was used the non parametric analysis and the result of Mann Whitney non parametric analysis, the value of Sig 2-tailed $=0.57$ with a 0.05 . it means that $\mathrm{H}_{0}$ is accepted. It is because the value of Asymp sig 2-tailed is above the alpha ( $\alpha$ ) value. This result showed that there
\end{abstract}


was not a significant effect of using vocabulary notebooks on students' vocabularu achievement at the second grades in SMP Negeri 2 Raha.

\section{Introduction}

Vocabulary is a kind of part of speech. Vocabulary is an important aspect of learning a language. Simpson and Weiner $(1989 ; 721)$ states that, "vocabulary is a collective of words with brief explanation of their meaning. Kridaklasana (1983) stated that "vocabulary is language component which make information about meaning and using of words in the language". In this case, the students will know the meaning of the sentences in the text, and the more vocabulary students' master. The more skills they will have in language learning.

The important of vocabulary as an element of language become the one aspect that the students should focus to increase their English ability. The researcher has observed in the classroom learning process of SMP Negeri 2 Raha which is the students were difficult to comprehend all of the fourth skill, namely listening , speaking, writing, and reading. In other word the students have lack of mastered the English material. It is make the students were difficult to express their idea caused students mostly just keep silence and sit quietly in their seat.

The researcher has found in the classroom activities in SMP Negeri 2 Raha, that the teacher do the teaching and learning process just serve material and doesnot focus to make the students have new words for every learning activities. The main problem in the classroom face by the students' of SMP Negeri 2 Raha in teaching and learning English are lack of English vocabulary and the lack of appropriate teaching technique in studying English. The effect of this teaching and learning process, the students got difficulties in learning vocabulary such as the students difficult in memorizing the meaning of the word.

Learning vocabulary as a foreign language seems easy but some students feel fear. The teacher of English should find out solution by creating efficient and effective technique teaching of teaching vocabulary. Brown $(1980 ; 7)$ stated that teaching is showing or helping someone how to do something, given instruction, guiding in the study of something providing with the knowledge, causing to know or to understand. Teaching is building and facilitating learning, enabling the learner to learn, setting the conditions for learning. It means teaching is a systematic way teacher as an organizer should be creative to make learner interested in following the subject.

In this matter, the teacher has important role which the English teacher is part of the students' in teaching learning process. The teacher is a facilitator in way prepared material and technique that suitable what the students need and want. Sudjana (2002) said that "a good learning environment, learning activities more interesting and not boring, so that students' motivation will be higher. In other word, the teacher should be smartly to find out the solution of the students' problem to master the English material given. Because, there was a good correlation between the material was given and technique teaching learning process. It is as possible as the purpose of all of side in education we can reach. 
That's way, the researcher takes one of the techniques in order that the students can develop their vocabulary and they will interest in teacher learning process. The researcher introduces "vocabulary notebooks". This treatment can be uses in the classroom to teach English, escpecially is to make students easy get the new vocabularies in their learning process. Teaching vocabulary is clearly more than just presenting new words in a list and asking students to memorize them. It is believed that learners will learn vocabulary well when they are actively involved in words learning and at different level of mental activity. Learners should be trained to work with words deeply, by working with collocated, looking at how the word is similar but different other words (Waring:2001). Vocabulary notebooks use with vocabulary materials allow students to active their previous knowledge and the students can know the meaning of the vocabulary. This condition will support the students to get the point of the English material.

Based on th explanation above, teacher should has the appropriate way to help the students develop the vocabulary.The researcher tries to contribute an idea to teaching English.Therefore, the researcher offers a method or technique of the learning vocabulary called "Vocabulary Notebook". The researcher hopes that this technique will be useful for the teachers in teaching and learning process, especially teaching vocabulary in SMP Negeri 2 Raha.

Based on the background above, the researcher determines the problem statements as follows:

1. Is there any significant effect of keeping vocabulary notebooks on students' vocabulary achievement at the second grades in SMPN 2 Raha?

\section{Methodology}

The design of this study was experimental design. The Subjects of the research was the students at SMPN 1 Kabawo. It was to see the effect of keeping vocabulary notebook on students' vocabulary achievement at the second grade in SMPN 2 Raha. That was to find out the students' vocabulary achievement when the students used vocabulary notebooks in learning process. The instrument of this study was vocabulary test. The test consisted 30 terms, namely multiple choice (15) fill in the blank (5) and matching word (10). The test was designed by the researcher and test items were taken from the English textbook for class VIII of Junior High School, as well as some additional test items from the researcher.

\section{Result and Discussions}

\section{The Students' Vocabulary Score on Post-test in Experimental Class and Control Class}

\section{Descriptive Analysis of Post-test in Experimental Class}

The distribution of students' score on post-test in experimental class was described below: 


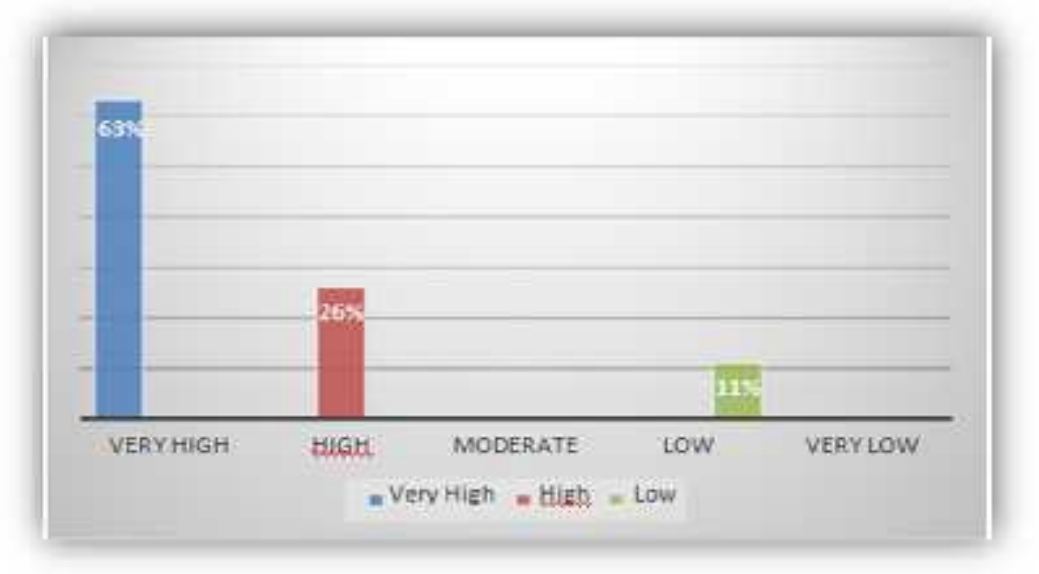

This graph categorizes the students' score in very high, high and low criteria. The students' score in experimental class it is about $63 \%$ of students classified as very high criteria. And it is about $26 \%$ of students that get score classified as high criteria. Unfortunately, there are $11 \%$ of students that classified as low criteria. It means that for some students there is an effect after used vocabulary notebooks in English learning process to develop the students' vocabulary achievement, but for $11 \%$ of students the used of vocabulary notebooks cannot increase the students' vocabulary achievement.

\section{Descriptive Analysis of Post-test in Control Class}

The distribution of students' score on post-test in control class was described below:

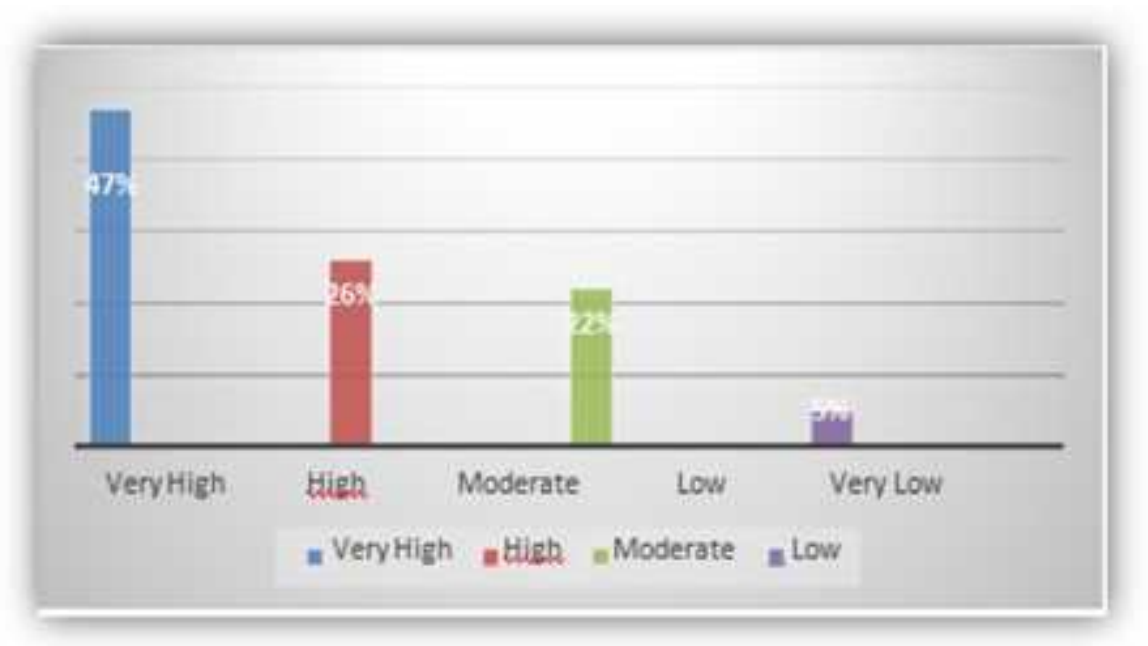

This graph categorizes the students' score into very high, high, moderate and low criteria. The students' score in control class it is about $47 \%$ of students classified as very high criteria. And it is about $26 \%$ of students that get score classified as high criteria. And there are $22 \%$ of students classified as moderate criteria. And then it is about $5 \%$ of students that classified as low criteria. It means that for some students in control class that learn without vocabulary notebooks in English learning 
process has not a significant effect to influence their vocabulary achievement. It is proved that only $5 \%$ that students' get low score in control class.

The Comparison of Post-test Score in Experimental Class and Control Class 1. Distribution of students' score on post-test in experimental class and control class

The distribution of classification teacher's feedback on direct feedback was described below:

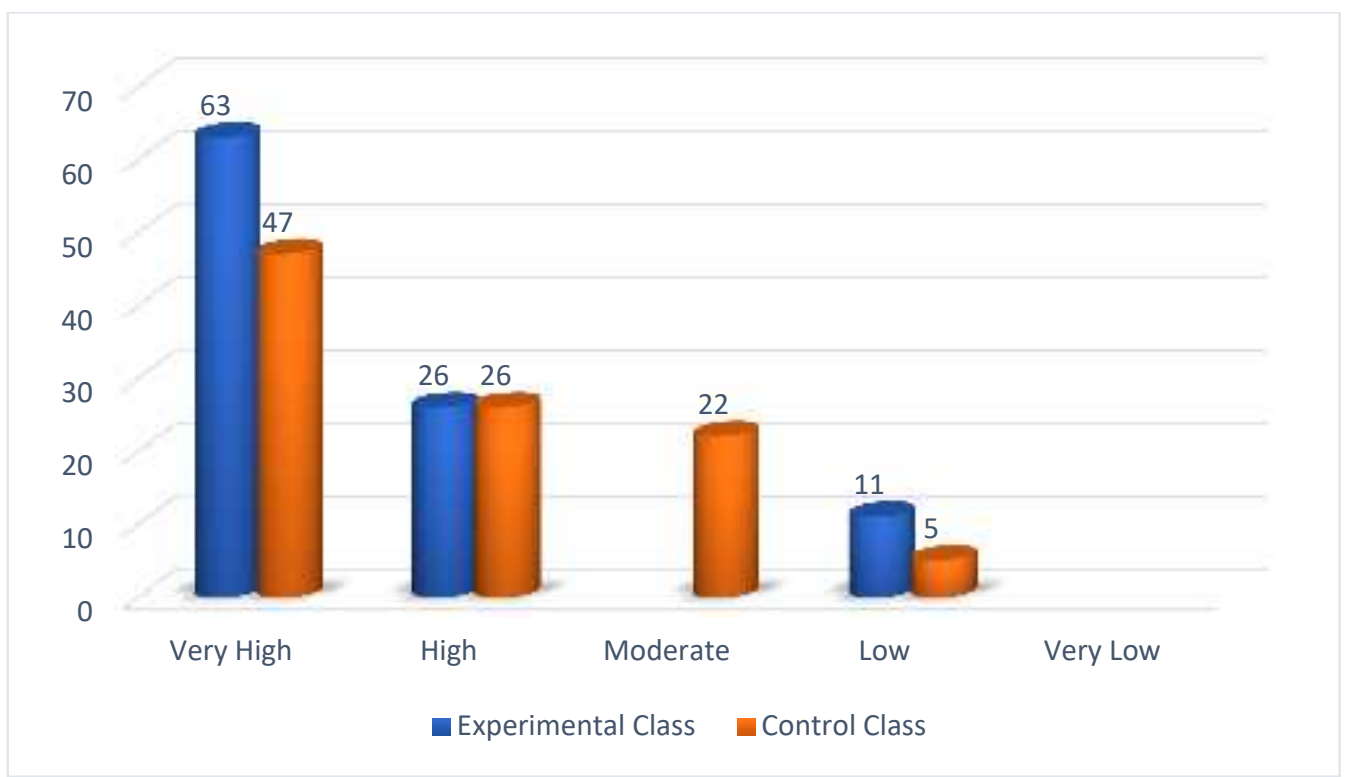

Based on the previous graph, it can be seen that the majority students in experimental class get very high score and the majority of students in control class get very high score. Therefore, the others students in experimental class high score that classified as high criteria. But students in control class and experimental class got balance in high criteria on students' vocabulary achievement. And then, the students in control class get the moderate criteria on their vocabulary achievement. It can be concluded that the students' vocabulary achievement in experimental class is higher than the students' vocabulary achievement in control class.

\section{Distribution of Students' Gain Score in Experimental Class and Control Class}

The distribution of students' gain score in experimental class and control class was described below: 


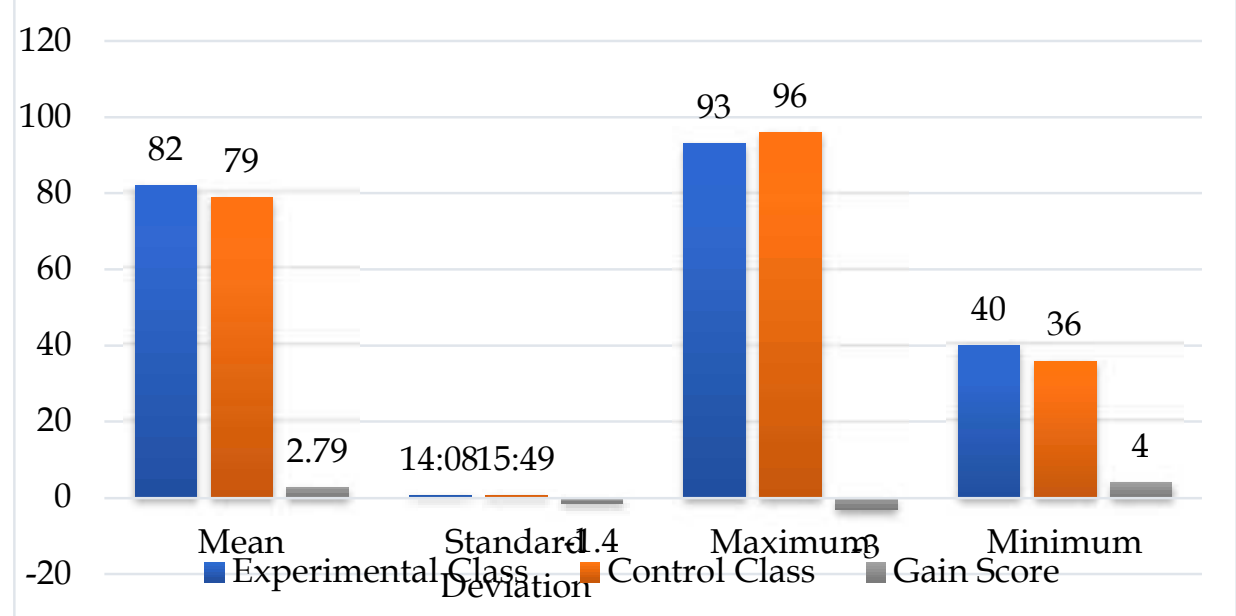

As can be seen from the previous table, it is clear that the students' average score in experimental class and the average in control class show difference. The mean of score on post-test in experimental class is 82.15 and in control class is 79.36 which the gain score is 2.79. The gain score of standard deviation in experimental class and control class is -1.4. The gain score of maximum score in experimental class and control class is -3 points. And then the gain score of minimum score in experimental class and control class is 4 points.

This fact revealed that teaching of English by keeping vocabulary notebooks in experimental class has a positive effect on students' vocabulary achievement. But in a control class the convention method that used by teacher when English learning process keep help students can get the good vocabulary achievement. Some of students, namely about $22 \%$ can get moderate criteria. And it is shows that without vocabulary notebook, students can get good achievement in their learning process.

\section{Discussion}

This study was conducted in SMPN 2 Raha from july to october 9th 2018 . The researcher took at the eighth grade, where class VIII ${ }^{2}$ as experimental class and class VIII $^{1}$ as control class. In this study, the researcher applied English learning to the students in experimental class by keeping vocabulary notebooks and in control class the learning process using conventional method. This resracher aims to find out the effect of keeping vocabulary notebooks on students' vocabulary achievement. In this case, the researcher wants to know the different from English learning process by both of methods on students' vocabulary achievement. To make sure the sample is homogeneous, the researcher asks the students to finish the test. In other words, with the score in this test, the researcher can know the prior knowledge of students in English subject.The researcher adopted the test from the book that the teacher used in the teaching and learning process. And the researcher starts the treatment with using vocabulary notebooks method in experimental class and using conventional method in control class. The researcher gives the treatment to the students during 5 meeting. Then, the researcher gives post-test in experimental and control class. 
After conducting the data of post-test in both of classes, the result of data analysis shows that the mean score of post-test in experimental class is 82.15 and the mean score of post-test in control class is 79.36. From this result we can see that the score from post-test in control class to post-test in experimental class is difference. It can be concluded that the keeping of vocabulary notebooks method can give an effect on students' vocabulary achievement after giving treatment in $5^{\text {th }}$ meetings, but this result can not give the significant effect to support the effectiveness of vocabulary notebook. In brief, vocabulary notebooks can make the students is easy to understand what they learned but it is difficult to help them increase their vocabulary achievement.

The process of learning the words of a language is reffered to as vocabulary achievement. The process by which one acquires the capacity to perceive and use words to understand and communicate (Laufer B;2011). Based on this theory, the researcher knows that to achieve the vocabulary of students it's need to understanding the vocabulary in their learning process. In this case, the students should make a sequence process by action to develop their vocabulary achievement. In breif, the implementation of vocabulary notebook as the media in English Learning process need long time treatment.

Studentsneed to form a long-term memory of the word or phrase to make students trying to remember.When students learn a new word in class or during self-study, it's in students short-term memory. Students are able to recognise and even use the word during the studies and maybe even for a short time.And then students may forget it. Students need to move the word into their long-term memory. The only way to do this is to see, hear and use the words many times.So thatwhy vocabulary notebook can not helpful for expanding their vocabulary more quickly in a short time,namely 5th meetings in English learning process.

Based on the data obtained, the researcher believes that keeping of vocabulary notebooks method is not better to apply in English teaching-learning process for the students who still lack in vocabulary. It supported by The result of Mann-Whitney Analyis as Non Parametric Analysis of Independent sample t-test showthat there is no effect of vocabulary notebooks on students' vocabulary achievement, the value of Sig $(2$-tailed $)=.587$ with $\alpha=0.05 . \mathrm{H}_{\mathrm{o}}$ is accepted and $\mathrm{H}_{\mathrm{a}}$ is rejected. This condition happened because the 9 students in control class that included as sample of researcher are got the very high score in vocabulary tested, namely 96 . But the students in experimental class only got 93 points as the very high score, although they are 12 students that classified as very high criteria. But the score in control class higher than experimental class.

The development of students English vocabulary at the second grade students especially in control class is more better than experimentl class can be caused of some factors. Firstly, the students who were taught by keeping vocabulary notebooks were more active in the classroom rather then in control class, that used conventional method, But the students in control class has good cognitive skill, the students in control class can finish the post-test well. in experiment class the students work with the vocabulary notebooks, it seemed that every student were active, but the students doesnot memorize the words well. It is relevant with Schmitt (1995) who said that one of step in using of vocabulary noteboooks, the process is students 
will defining and explaining vocabualary including : part of speech, sentence, synonym, and antonym. Because of that the students work individually with a vocabulary notebooks. Secondly, the students can better memorize with what they have wrote by themselves rather than telling directly the words to them. It is supported by Bonwell (1998) who said that learning is process oriented rather than content oriented. And the last, the students who work with the vocabulary notebooks looked more interest to find out the meaning, synonym, antonym of the vocabulary.

Besides that, the researcher find some problems when keeping vocabulary notebooks in the classroom. First, the students sometimes still difficult to understand the instruction from the teacher because the students don't know exactly what is the meaning of the teacher said. It is because some of students still lack in vocabulary knowledge, for the first meeting which used vocabulary notebooks in the classroom the researcher spends more time in explain some instruction that the students will do in their classroom. But, for the next meetings the researcher can manage the time well so the researcher can apply the keeping of vocabulary notebooks in classroom effectively especially in vocabulary activity.

The researcher also find that the students in experimental class who fill the vocabulary notebooks cannot memorize the word well, because they do the test, they cannot answer the test correctly, although the vocabulary already wrote on their vocabulary notebook. Therefore, using a vocabulary notebook is a learning process which should be personal to students make students get an experiment with different ways of recording meaning. The use of vocabulary notebooks is better to increase students' vocabulary achievement because the students learn by doing in their real situation. In short, the using of vocabulary notebooks is an appropriate method to increase students' vocabulary achievement, but is should be applied on long time to make the effectiveness of the vocabulary notebooks it's self.

\section{Conclusion}

Based on the finding of the study, it can be concluded that there is no significant effect of vocabulary notebooks on students' vocabulary achievement Altough, students' score who are taught by vocabulary notebooks method get the high mean score in vocabulary achievement. It can be seen that the mean score of post-test in experimental class is 82.15 is higher than the mean score of post-test in control class is 79.36. The students cannot get the highest score aslike asin control class which used conventional method. The highest score in class control is 96, meanwhile student in experimental class only get 93 as the highest score.

In short, after considering some findings in this study,especially the analysis of Mann-Whitney test the researcher conclude that teaching English by keeping vocabulary notebooks cannot give any significant effect on students' vocabulary achievement.

\section{Refferences}

Allen, F.V. (1983). Techniques in Teaching Vocabulary. Oxford: Oxford University Press. 
Arikunto, S. (2006). Metode Penelitian: Suatu Pendekatan Praktik. Jakarta: Rhineka Cipta.

Emzir. (2008). Metodologi Penelitian Kuantitatif dan Kualitatif. Jakarta: Raja Grafindo Persada.

Fraenkel \& Wallen (2000). Educational Research: A Guide to The Process. Newyork: The Free Press

Finocchiaro,M. (1974). English as a Second Language: from Theory to Practice.

Newyork: Regents Publishing Company.

Fowle , C. (2002). Vocabulary Notebooks: Implementation and outcomes. English Teaching Journal, 56(4), 380- 88.

Harmer, Jeremy. (2002). The Practice of English Language Teaching 3rd Edition. London: Longman.

Hatch, E.V., and Brown, C. (1995). Vocabulary, Semantics, and Language Education. Cambridge: Cambridge University Press.

Hornby,A. (1974) Oxford Advances Learner's Dictionary of Current English Edisi III. London: Longman.

Kridalaksana, Harimukti (1983). Kamus Linguistik. Jakarta:Gramedia

Nurbaya, S and Melvina. (2014). Improving Students Vocabulary Mastery by Using Vocabulary Notebooks at grade V.C of SDN 025 Bukit Raya Pekan Baru. Sumatera Barat: STKIP PGRI.

Nation, I.S.P. (1990). Teaching and Learning Vocabulary. Newyork: Newbury House.

Mason, E.J \& Bramble, W.J. (1997). Research and Education and the Behavioral Science. Chicago: Brown and Benchmark.

Richard, M. \& Spurlin J. (2005). Applications, Reliability and Validity of the Index of Learning Styles. North Carolina State University: Tempus Publications

Simpson J \& and Weiner. (1989). The Oxford Encyclopaedic English Dictionary. Oxford: Clarendon Press.

Sufiani, A.A (2014). The Effect of Word Box to Improve the Students Vocabulary Achievement. Kendari: Halu Oleo University.

Schmitt,N \& McCharty. (1997). Vocabulary Acquisition and Pedagogy. Cambridge: Cambridge University Press.

Schmitt, N and Schmitt, D. (1995). Vocabulary Notebooks : Theoritical Underpinnings and Practical Suggestions. Cambridge: Cambridge University Press.

Sugiyono (2010). Metode Penelitian Pendidikan Pendekatan Kuantitatif, Kualitatif, dan R\&D. Bandung:Alfabeta.

Tarigan, Henry. (1989). Pengajaran Kosakata. Bandung: Angkasa. 
Trihendradi, Cornelius. (2005). Step By Step SPSS 13: Analisis Data Statistik. Yogyakarta: Penerbit Andi

Ur, Peny. (1966). A Course of Language Teaching. Newyork: Cambridge University Press.

Waring,R. (2001). Getting Your Students' to Use Their Dictionaries Effectively. Tokyo:Oxford University Press.

Wilkins, D (1972). Linguistic in Language Teaching. London: Edward Arnold. 